\title{
Soil corrosivity and aquifer protective capacity of overburden units in Ado-Ekiti, southwestern Nigeria
}

\section{Preiskava korozivnosti tal in sposobnosti površinskih plasti za varovanje vodonosnikov na ozemlju Ado-Ekiti v jz Nigeriji}

\author{
Oyedele, A.A. ${ }^{1, *}$, Olayanju, G.M. ${ }^{2}$, Talabi, A.O. ${ }^{3}$, Ogunyebi, S.N. ${ }^{4}$, Ojo, O.F. ${ }^{3}$ \\ ${ }^{1}$ Department of Physics, Ekiti State University, Ado-Ekiti, Nigeria \\ ${ }^{2}$ Department of Applied Geophysics, Federal University of Technology, Akure, Nigeria \\ ${ }^{3}$ Department of Geology, Ekiti State University, Ado-Ekiti, Nigeria \\ ${ }^{4}$ Department of Mathematical Sciences, Ekiti State University, Ado-Ekiti, Nigeria \\ *akinakin02@yahoo.com
}

\begin{abstract}
Vertical electrical sounding, well inventory and physicochemical analysis were conducted to evaluate soil corrosivity and aquifer protective capacity of overburden units in the basement complex terrain of Ado-Ekiti, southwestern Nigeria. The topsoil is composed of slightly corrosive materials at the eastern, southern and northeastern flanks and the central portion with resistivity values ranging from 60 to $180 \Omega \mathrm{m}$. Moderately corrosive/slightly corrosive materials (with resistivity values of $10<\rho<60 \Omega \mathrm{m}$ ) constitute the second layer around the eastern, southern and northeastern flanks. Pockets of areas in the northwestern, southeastern, eastern and central parts of the metropolis are practically non-corrosive with resistivity values in excess of $200 \Omega \mathrm{m}$. Zones of good, moderate, weak and poor overburden protective capacity were delineated, with longitudinal conductance $(S)$ values of $0.7<S<4.9,0.2<S<0.69,0.1<S<0.19$ and $S<0.1$ mhos, respectively. On a regional consideration, $23.31 \%, 18.80 \%$ and $57.9 \%$ of the study area is characterised by overburden materials of poor, weak and moderate protective capacity, respectively. Only $6.02 \%$ of the area indicates good overburden protective capacity.
\end{abstract}

Key words: Ado-Ekiti, Contaminant, Corrosivity, Geoelectrical Survey, Protective Capacity

\section{Povzetek}

Vertikalno električno sondiranje, preiskavo vodnjakov in fizikalnokemično analizo so opravili z namenom oceniti korozivnost tal in sposobnost površinskih plasti tal za varovanje vodonosnika na ozemlju kamnin podlage Addo-Ekiti v JZ Nigeriji. Vrhnja plast tal na vzhodnih, južnih in severovzhodnih delih in v osrednjem delu ozemlja sestoji iz nizko korozivnih sestavin z električno upornostjo med 60 in $180 \Omega \mathrm{m}$. Nizko do zmerno korozivne sestavine (z upornostjo $10<\rho<60 \Omega \mathrm{m}$ ) tvorijo drugo plast na vzhodnih, južnih in severovzhodnih delih terena. Krpe ozemlja v severozahodnih, jugovzhodnih in osrednjih delih prestolnice so pa praktično nekorozivne z vrednostmi upornosti, večjimi od $200 \Omega$ m. Površinske cone tal z dobro, zmerno, nizko in neznatno varovalno sposobnostjo so omejili z ozirom na vrednosti vzdolžne prevodnosti $(S)$, in sicer $(0.7<S<4.9)$, $(0.2<\mathrm{S}<0.69),(0.1<\mathrm{S}<0.19)$ in $\mathrm{S}<0.1$ mhos. Regionalno gledano pripada $23.31 \%, 18.80 \%$ in $57.9 \%$ preiskovanega ozemlja površinskim materialom neznatne, nizke in zmerne varovalne sposobnosti. Samo 6,02\% površine ima površinske plasti z nakazano dobro varovalno sposobnostjo.

Ključne besede: Ado-Ekiti, onesnaženje, korozivnost, geoelektrična preiskava, varovalna sposobnost 


\section{Introduction}

Performance of civil engineering construction works including utility pipes requires knowledge about the corrosivity of soil. Soil supports man-made structures of all kinds; utilities and infrastructure are buried in it. Buried pipes are susceptible to corrosion and subsequent failure if the host soil medium is corrosive and aggressive. Corrosion refers to the degradation of buried metallic materials whereby metallic substrates are converted into oxides, hydroxides and aqueous salts within a cathode-anode system with corresponding loss in strength, ductility and other mechanical properties. Corrosion of cast iron, ductile iron and steel in soils can lead to a wide range of failures that are often accompanied by a high degree of economic and environmental consequences. For instance, leakage or rupture in pipelines could constitute hazards to the environment. Mitigating measures during design and construction as well as an understanding of the corrosive potential in a given soil environment are thus desirable [1-3]. Soil corrosivity depends largely on the composition of the soil and other environmental factors such as the moisture content, presence of oxygen, $\mathrm{pH}$ value, content of dissolved salts and porosity (aeration). The presence and abundance of oxygen promote corrosivity. High concentrations of soluble salts, high moisture content and a $\mathrm{pH}$ indicative of an acidic medium readily promote corrosivity. These factors control the soil resistivity. They are thus the main diagnostic factors. There exists a good correlation between the soil resistivity and corrosion rate of the buried metallic materials. Soil corrosivity is inversely related to the soil resistivity [2-4].

Contamination of the hydrogeologic system in metropolitan areas is increasing and has thus led to a critical issue in groundwater quality considerations. Installation of facilities, though essential but capable of provoking permanent damage of the underlying aquifers particularly in areas where residents rely mostly on groundwater, mandates an understanding of the aquifer protective capacity of the overburden units of the host soil medium. The overburden encompasses all geomaterials above the presumably fresh bedrock. Urbanisation and industrialisation remain the predominant con- tributors of contaminants to the hydrological systems. Leachate from dumpsites, mining activities, buried petroleum pipes/tanks and septic tanks and the widespread use of chemical products such as pesticides, herbicides and solvents portend risks to the groundwater quality status [5-7].

The subsurface layers act as a natural filter to imposed surface pollutants. The ability of the geomaterials to retard and filter percolating fluid is a measure of the protective capacity and a function of transmissivity. Estimating these properties from the traditional methods of pumping tests can be very expensive and time consuming. The electrical resistivity method is significant in in situ determination of subsoil characteristics and conditions [7-9].

The traditional purpose of electrical resistivity survey is to determine the resistivity distribution of the subsurface by taking measurements on the ground surface. The electric conduction in the subsurface is essentially electrolytic through interstitial water in pores and fissures. Groundwater filling the pore spaces constitutes a natural electrolyte with a considerable amount of ions. Soil environments have requisite electrolytic properties for the redox (oxidation-reduction) reactions that take place during corrosion. Soil resistivity indicates the ability of a soil environment to carry corrosion currents $[10,11]$. It is noted that burial of utilities and underground storage tanks are restricted to shallow depths.

In the present study, we seek to evaluate the corrosivity and protective capacity offered by the overburden units in the study area.

\section{Geology and description of location}

The study area, Ado-Ekiti, southwestern Nigeria, lies within latitudes $7^{\circ} 32 \$$ and $7^{\circ} 42^{\prime} \mathrm{N}$ and longitudes $5^{\circ} 9^{\prime}$ and $5^{\circ} 22^{\prime} \mathrm{E}$ (Figure 1 ). The area is underlain by the basement complex of southwestern Nigeria comprising the migmatite-gneiss-quartzite complex, charnockitic and dioritic rocks, older granites and unmetamorphosed dolerite dykes. Charnockite and quartzite ridges, which rise abruptly above the surrounding country rocks, are found in the area (Figure 2). Ado-Ekiti experiences a tropi- 


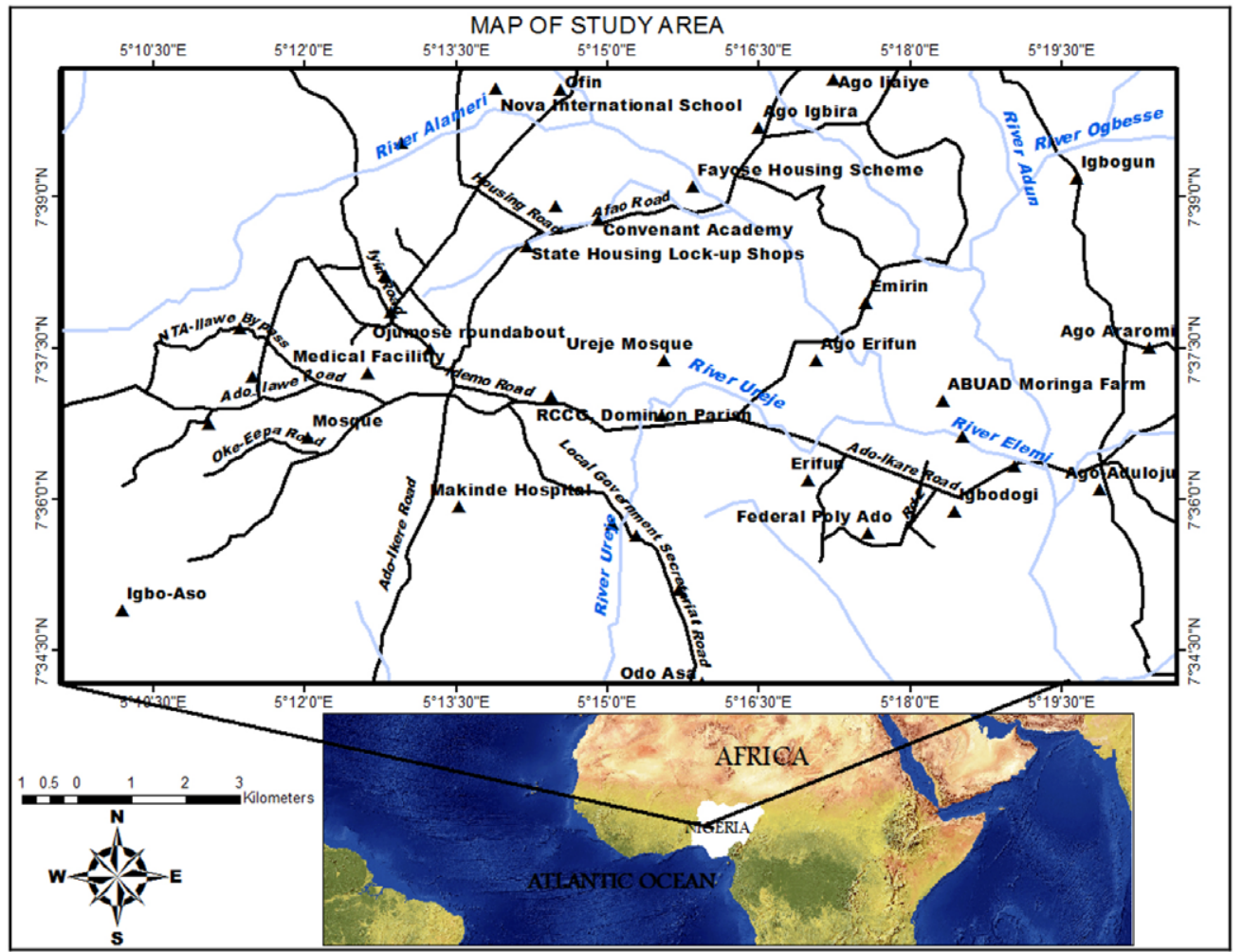

Figure 1: Location map showing the study area (adapted from Google Maps).

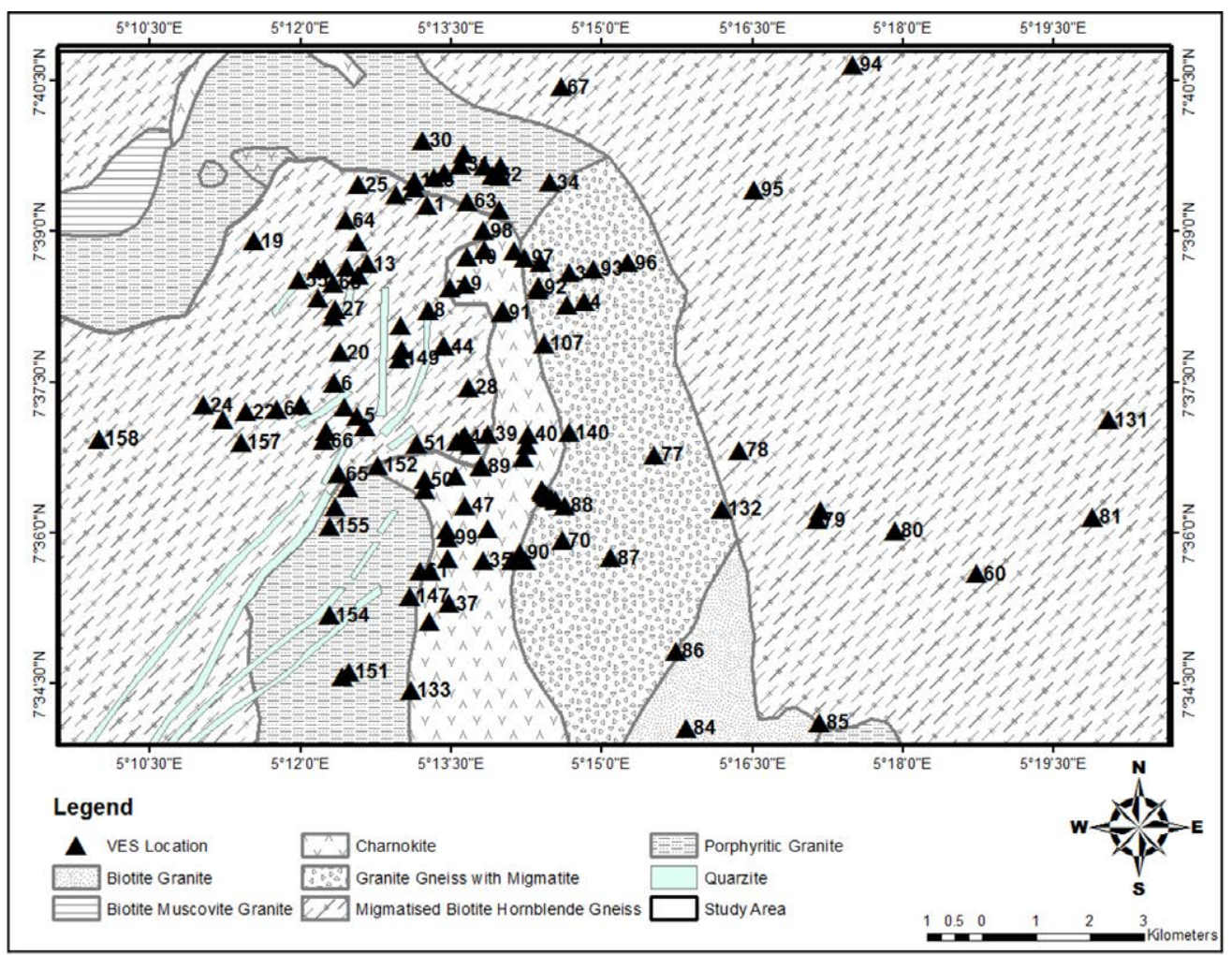

Figure 2: Geological map of Ado-Ekiti showing the VES points. 
cal climate with distinct wet and dry seasons. The major rivers draining the area include $\mathrm{Al}$ amoji, Ireje and Elemi $[12,13]$.

\section{Materials and methods}

Soil corrosivity is not a directly measurable parameter. One of the proven classifications of soil corrosivity towards the buried metallic materials is based on a single parameter, the soil resistivity. The soil resistivity reflects the main soil properties as it depends on porosity, degree of electrolyte saturation or concentration of dissolved salts in soils. It is thus typically indicative of soil corrosivity. The resistivity method has been adopted for this study $[2,14,15]$.

Well inventory data were obtained from 107 hand-dug wells across the metropolis including physicochemical analysis to secure information on groundwater presence and composition, which readily influence the resistivity. Parameters such as electrical conductivity (EC), $\mathrm{pH}$, temperature and total dissolved solids (TDS) were measured in situ in the field [16].

The geoelectric layer parameters were acquired using the Schlumberger arrays of vertical electrical sounding (VES) at 133 locations spread across the study area. ABEM Terrameter SAS 300B with ABEM 2000 booster was used for the measurement of resistance. The apparent resistivity values obtained were plotted against $(\mathrm{AB} / 2)$ or half the spread length at each station on a bilogarithmic (log-log) paper. Partial curve matching of field curves with relevant Schlumberger-developed master and auxiliary curves were used to obtain the resistivity values and corresponding thicknesses of the layers. The geoelectric parameters from this manual interpretation were improved upon by using the computer iteration algorithm RESIST Version 1.0 [17].

Depth sounding curves were inspected to determine the number and nature of the layering. The total longitudinal unit conductance, $S$, for the VES points was computed with the layer parameters as inputs $[7,9,10]$. Each VES station was georeferenced. ArcGIS 10.2.2 was used for the spatial distribution and thresholding of the data.
Otherdatainputsincluded soilmap3000/853/965 drawn by the Ministry of Agriculture and Natural Resources on 1:500,000 scale, geological map 3300/6/66/3289/OS prepared by the British Government's Ministry of Overseas Development on 1:250,000 scale and topographical sheet 1000/404/6.68 compiled and drawn by the Federal Survey from photo reduction 244 (Ado-Ekiti), 245 (Ikole), 264 (Akure) and 265 (Owo). Soil characteristics in the study area were considered. The major soil associations found in the study area were evaluated on the account of the type of soil and the associated water-holding capacity.

A Garmin 12-channel global positioning system (GPS) was used to obtain the eastings (longitude), northings (latitude) and elevation above the mean sea level of each point of interest during the fieldwork.

\section{Results and discussion}

\section{Field measurements and hydrochemical analyses}

The inventory of the shallow-dug wells revealed a depth range of $2.40-14.10 \mathrm{~m}$ with a mean value of $6.65 \pm 2.47 \mathrm{~m}$ and a static water level of 1.55-13.12 $\mathrm{m}$ with a mean value of $5.89 \pm 2.35 \mathrm{~m}$. The occurrence of groundwater is controlled by a number of factors such as type of parent rock, depth, extent and pattern of weathering, the sand/clay ratio and the degree of fracturing, fissuring and jointing $[18,19]$.

The shallow groundwater system is characterised by low values of TDS (average $33.57 \mathrm{mg} / \mathrm{L}$ ), EC of $0.79-77 \mathrm{~ms} / \mathrm{cm}$ (average $13.20 \mathrm{~ms} / \mathrm{cm}$ ), pH values of $3.50-8.20$ (average 6.50) and total hardness of $20-420 \mathrm{mg} / \mathrm{L}$ (average $112.23 \mathrm{mg} / \mathrm{L}$ ). Concentrations of major cations are in the order of $\mathrm{Ca}>\mathrm{Mg}>\mathrm{Na}>\mathrm{K}$ with average values of 51.76, 51.29, 8.60 and $6.59 \mathrm{mg} / \mathrm{L}$, respectively. Bicarbonate and chloride are the dominant anions with average concentrations of 87.70 and $53.38 \mathrm{mg} / \mathrm{L}$, respectively. High chloride content plays a major role in the corrosivity of buried metallic materials. Dissolution reactions of many metallic materials involve chlorides $[3,5,14]$.

The corrosion process is enabled by the electrolyte between the anodic and cathodic sites. The 


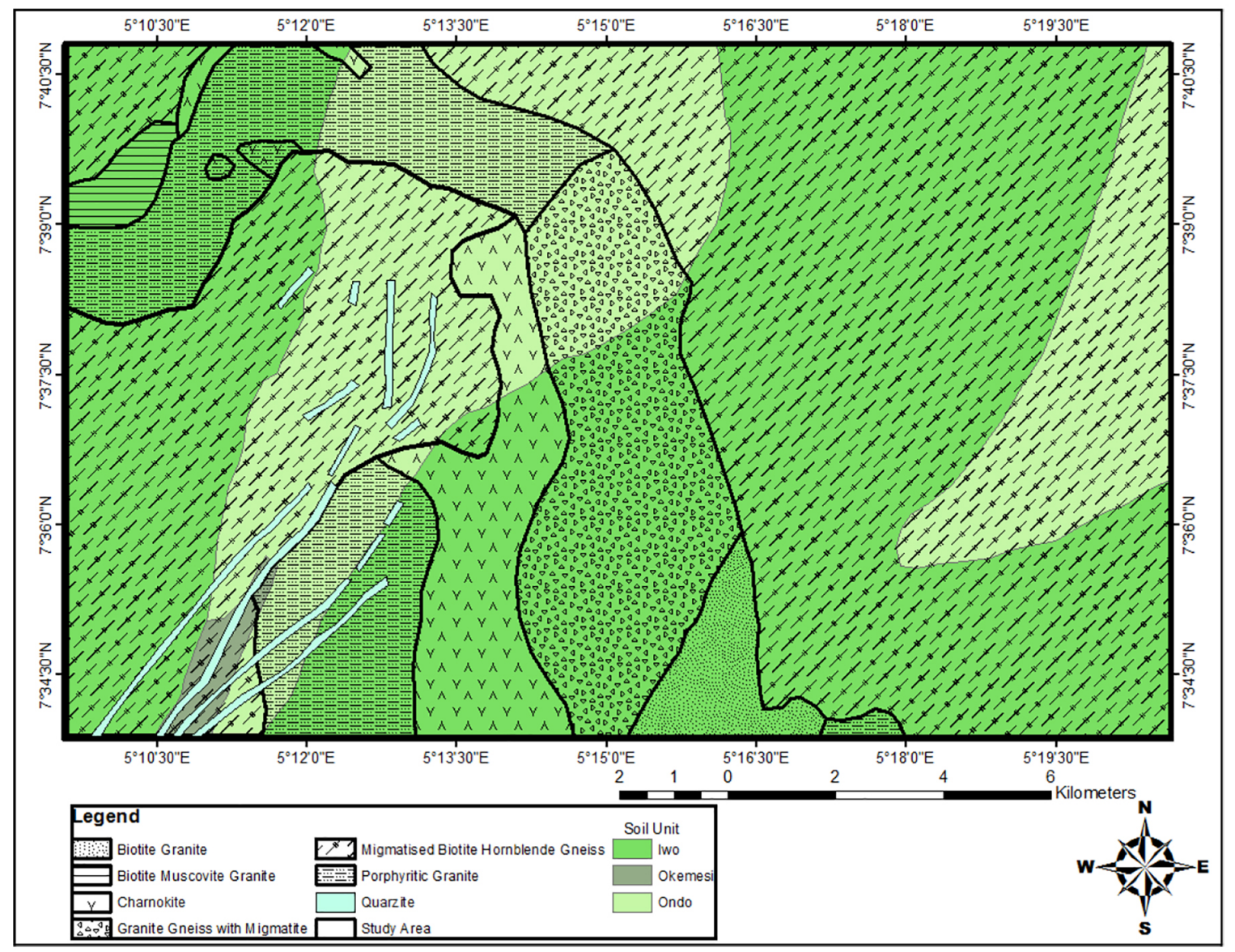

Figure 3: Soil map of Ado-Ekiti.

moisture content of soil acts as an electrolyte in the form of soluble salts such as chlorides and sulphates. The moisture content in typical soil samples collected at a depth of $1 \mathrm{~m}$ at the OdoAdo area of the metropolis was found to be in the range of $12.1-30.4 \%$. In general, clayey and humus soils hold maximum moisture content than sandy and gravelly soils. An acidic $\mathrm{pH}$ value indicates a good electrolyte as more hydrogen ions are available to act as electron acceptors. Slightly acidic/alkaline soil $\mathrm{pH}$ levels tend to decrease the soil resistivity and promote corrosivity. High soil resistivity slows down the corrosion activities due to less ionic current flow. Resistivity is thus a function of moisture and the concentration of current-carrying soluble ions. Low electrical resistivity is indicative of good electrical conducting path arising from reduced aeration, increased electrolyte saturation or high concentration of dissolved salts in soils $[3,15,16]$.

\section{Geoelectric type curves}

The characteristics of geoelectric curves varied greatly as typical of the basement complex terrain. They include the $\mathrm{A}, \mathrm{AA}, \mathrm{H}, \mathrm{HA}, \mathrm{HK}, \mathrm{K}, \mathrm{KH}$, $\mathrm{Q}$ and $\mathrm{QH}$ curve types and combinations with the H-type curve accounting for $18.11 \%$. This is an indication of the degree of weathering and fracturing $[1,7,20]$.

\section{Evaluation of soil corrosivity}

The three major soil units distributed across the study area include the Iwo, Ondo and Okemesi Associations (Figure 3). The nature of residual soils in the study area is determined by the underlying geology. The rates of infiltration and permeability are directly interrelated to soil characteristics. The Iwo soil type is underlain by coarse-grained granite, gneiss and charnockite. The soil is composed of coarse-textured, greyish brown to brown sandy, fairly clayey soils. The soil type is widespread in the study 


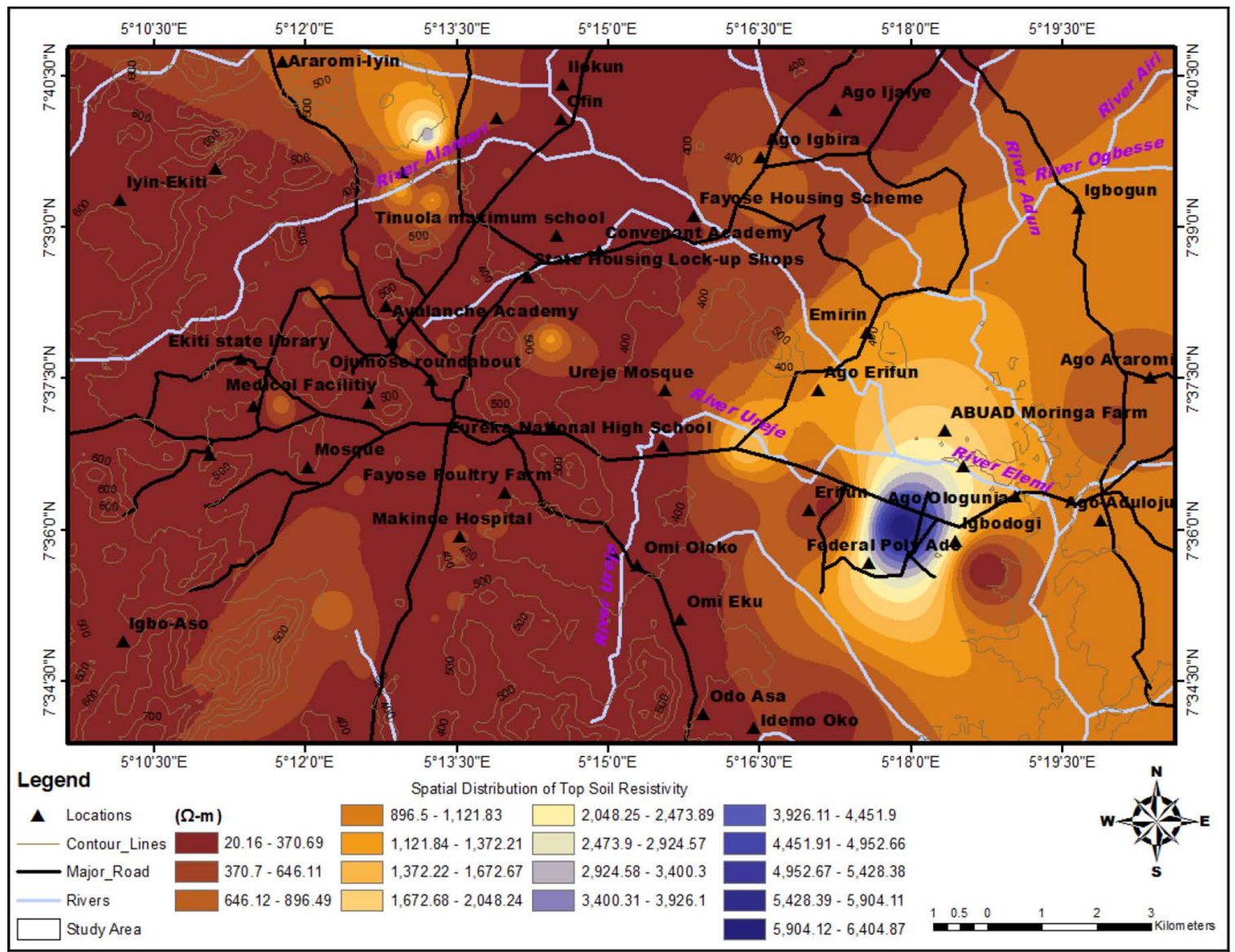

Figure 4: Resistivity of the topsoil.

area. The sandy nature of this soil promotes infiltration. The Ondo association is found on medium-grained granite and gneiss underlain areas. The soil comprises fine- to medium-textured, orange brown to brownish red, fairly clayey soils overlying orange, brown and red mottled clay. The Okemesi association is located on quartz schists and gneisses. The soil is composed of very coarse-textured, gravelly, pale grey brown to brown, usually sandy soil [21]. The topsoil in the metropolis varied in composition from clay, sandy clay, clayey sand to sand and laterite with the topsoil resistivity values ranging from 18 to $6410 \Omega \mathrm{m}$. The highest \% frequency occurred in the resistivity values between 100 and $200 \Omega \mathrm{m}$. The low resistivity end $(\rho<1000 \Omega \mathrm{m})$ is diagnostic of alluviumsand horizon, while the high resistivity end $(\rho>1000 \Omega \mathrm{m})$ typifies laterites and compact sand. The wide resistivity range is a consequence of the variable composition of this layer, degree of fluid saturation (or moisture content) and degree of compaction. Moisture content in soil is significant when considering corrosion potential. A dry soil environment is associated with a high resistivity with practically no corrosion potential. The resistivity decreases rapidly, and corrosion is promoted with increases in moisture content until the saturation point is reached $[15,18,19]$. The thickness of the topsoil is commonly around $1.3 \mathrm{~m}$.

Tables 1 and 2 give classification of soil corrosivity in terms of resistivity. The frequency distribution of corrosivity level within the topsoil is presented in Figure 5. Topsoil materials indicating corrosivity levels of practically non-corrosive (PNC), slightly corrosive (SC) and moderately corrosive (MC) had coverage of $48.87 \%$, $39.1 \%$ and $12.03 \%$, respectively. 
Figure 5: Corrosivity level of the topsoil..

Table 1: Soil electrical resistivity/corrosivity classification (BS-1377).

\begin{tabular}{cc} 
Soil resistivity $(\Omega \mathbf{m})$ & Soil corrosivity \\
\hline$<10$ & Severe \\
\hline $10-50$ & Corrosive \\
\hline $50-100$ & Moderately corrosive \\
\hline$>100$ & Slightly corrosive \\
\hline
\end{tabular}

Table 2: Classification of soil resistivity in terms of corrosivity $[20,22,23]$.

\begin{tabular}{cc} 
Soil resistivity $(\Omega \mathbf{m})$ & Soil corrosivity \\
\hline$<10$ & $\begin{array}{c}\text { Very strongly } \\
\text { corrosive (VSC) }\end{array}$ \\
\hline $10-60$ & $\begin{array}{c}\text { Moderately } \\
\text { corrosive (MC) }\end{array}$ \\
\hline $60-180$ & $\begin{array}{c}\text { Slightly } \\
\text { corrosive (SC) }\end{array}$ \\
\hline$>180$ & $\begin{array}{c}\text { Practically } \\
\text { noncorrosive (PNC) }\end{array}$ \\
\hline
\end{tabular}

A large portion of the metropolis ( $\%$ frequency of $48.87 \%$ ) is practically non-corrosive with resistivity values of $\rho>180 \Omega \mathrm{m}$ within the topsoil, particularly areas overlain by lateritic hardpan with relatively high resistivity values. Relatively low resistivity values are indicative of high tendency for corrosivity. Slightly corrosive materials with resistivity values of $60<\rho<180 \Omega$ m occupy $39.10 \%$ of the topsoil and are observed at the eastern, southern, northeastern flanks and the central portion. Moderately corrosive topsoils with resistivity values of $10<\rho<60 \Omega \mathrm{m}$ are delineated around Eureka/Oke Ureje (Figure 6).

The second layer coincides with the regolith of the H- and HA-type curves, which predominates the area with $18 \%$ and $14 \%$ occurrence, respectively. The layer is characterised by resistivity values ranging from 3.2 to $5200 \Omega \mathrm{m}$ (Figure 7). The low resistivity end $(\rho<60 \Omega \mathrm{m})$ is diagnostic of silt or clay horizon with little or no sand content. The resistivity values reflect the varying degree of weathering, the bedrock 


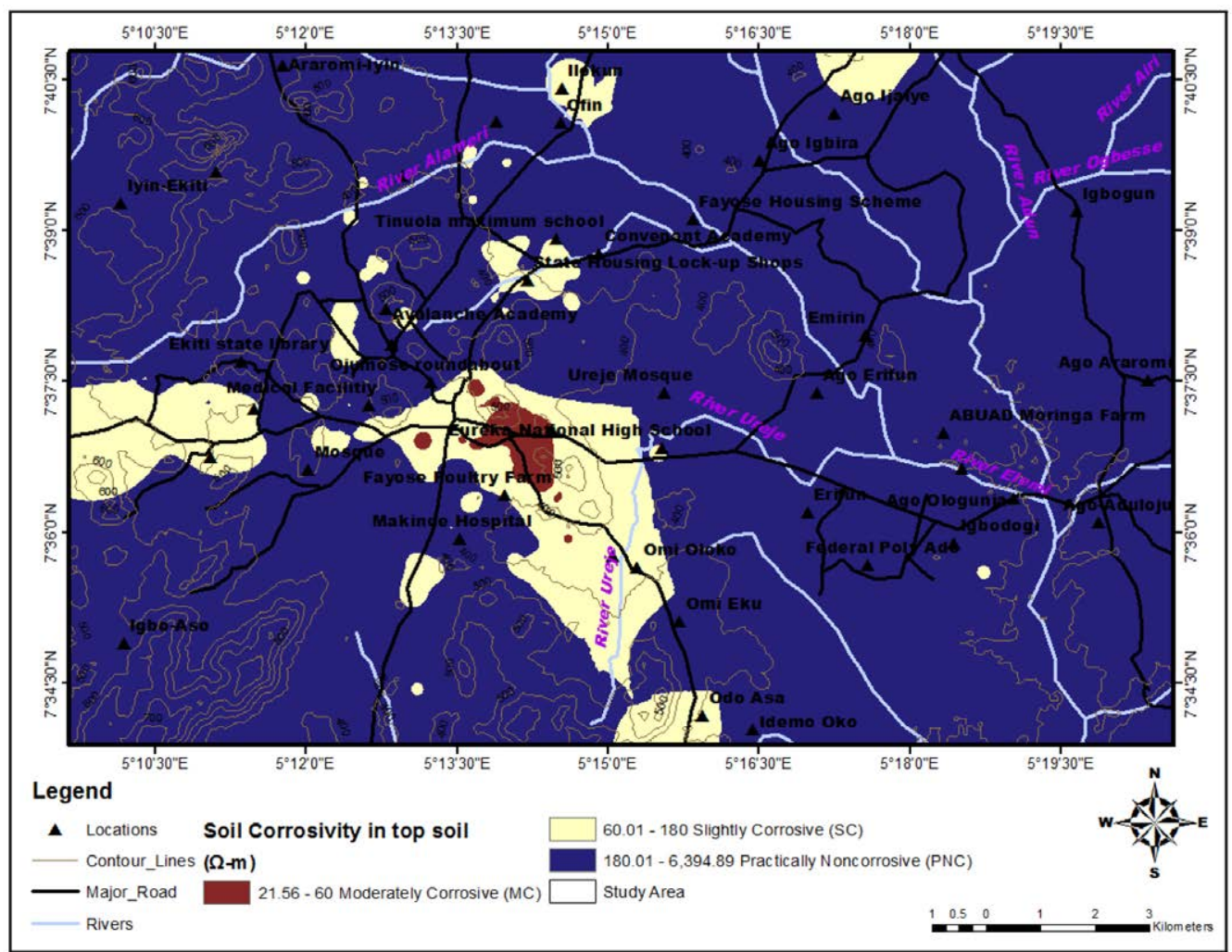

Figure 6: Corrosivity map of the topsoil.

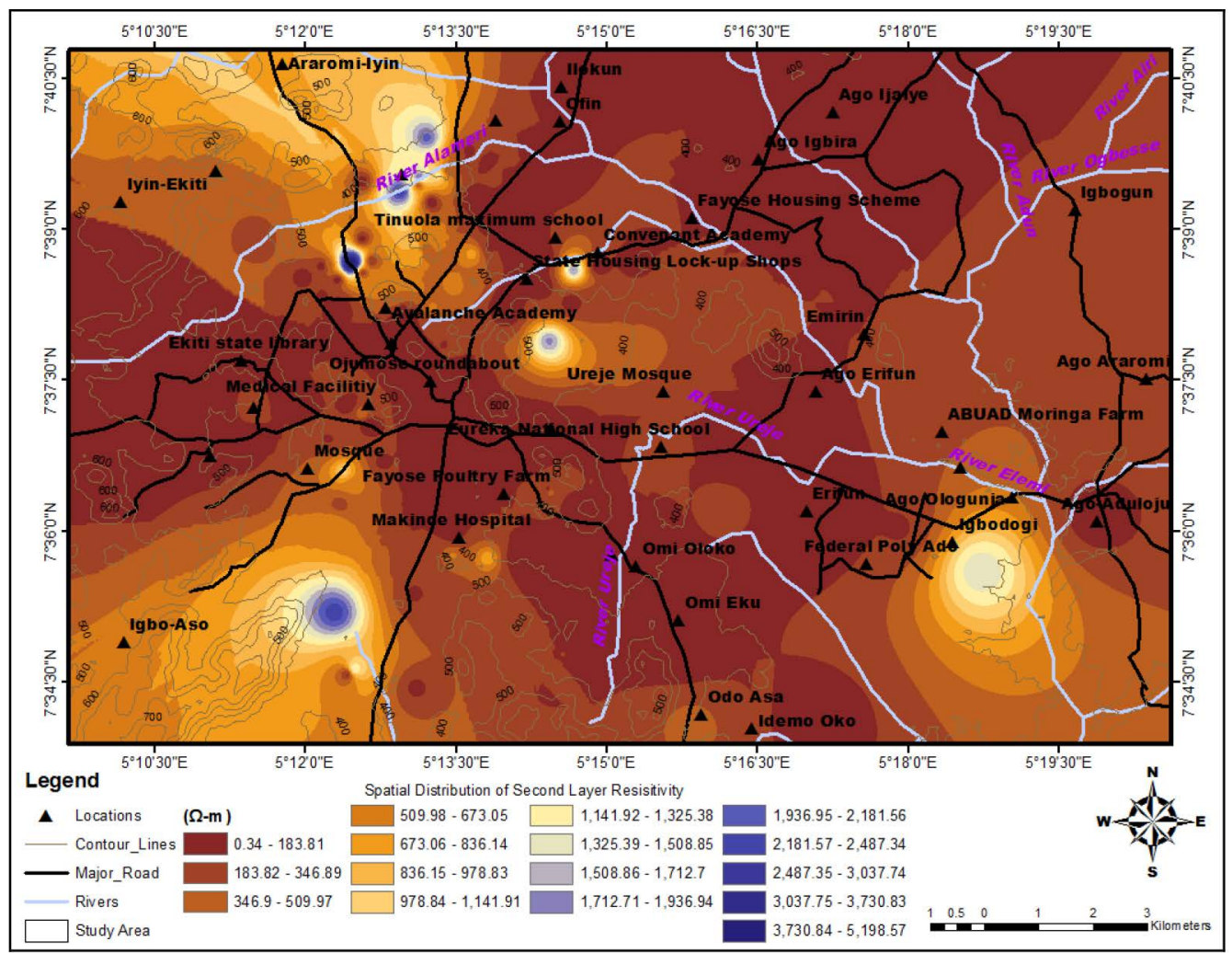

Figure 7: Resistivity map of the second layer. 


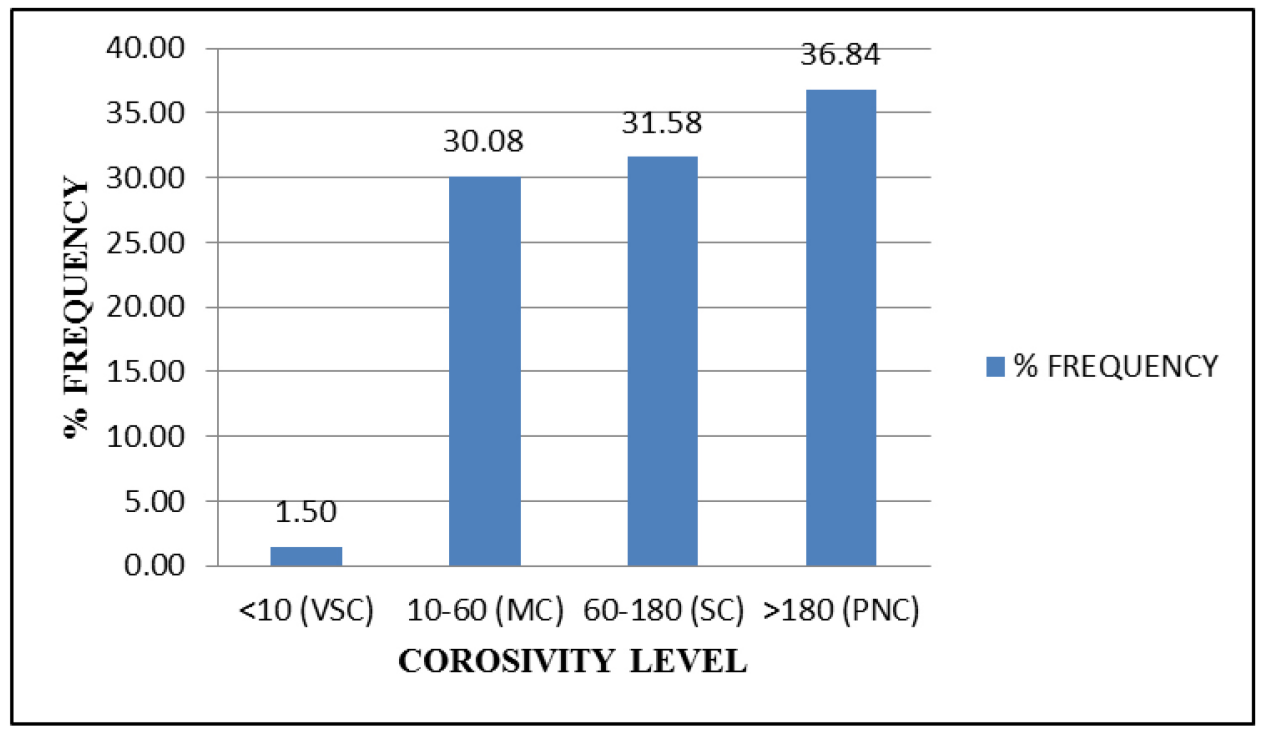

Figure 8: Corrosivity level of the second layer.

structure and mineralogy. It is typically clayey with low layer resistivity values $(\rho<100 \Omega \mathrm{m})$ over basic charnockite and sandy/clayey sand $(\rho>100 \Omega \mathrm{m})$ on fine-coarse-grained granitic/ gneissic rocks. Formation of a clayey regolith is enhanced with intense chemical weathering of the parent rocks.

The soil corrosivity within the second layer indicates a frequency distribution (Figure 8) of $1.5 \%, 30.08 \%, 31.58 \%$ and $36.84 \%$ for VSC, MC, SC and PNC levels, respectively. Figure 9 shows moderately corrosive/slightly corrosive materials around the eastern, southern and northeastern flanks. The northwestern, southeastern, eastern and central parts of the metropolis are practically non-corrosive with resistivity values of $\rho>180 \Omega \mathrm{m}$, indicating reduced porosity and negligible fluid content and degree of saturation.

\section{Evaluation of the aquifer protective capacity}

The longitudinal unit conductance varies widely (0.01-4.40 mhos) across the metropolis (Figure 10). The parameter presents the combination of the thickness and resistivity of the geoelectric layers into a single variable. The qualitative use of this parameter is to demarcate changes in the total thickness of low-resistivity materials, hence its utilisation for evaluating the protective capacity of overburden units in an area $[7,20,24]$. A clayey overburden that is highly impervious presupposes relatively high longitudinal conductance and offers effective protection to the underlying aquifer.

Figure11 shows the overburden protective capacity distribution of the study area. The protective capacity of the overburden has been zoned into good, moderate, weak and poor (Table 3).

Table 3: Longitudinal conductance/protective capacity rating $[7,24]$.

\begin{tabular}{cc}
$\begin{array}{c}\text { Longitudinal } \\
\text { conductance (mhos) }\end{array}$ & $\begin{array}{c}\text { Protective } \\
\text { capacity rating }\end{array}$ \\
\hline$>10$ & Excellent \\
\hline $5-10$ & Very good \\
\hline $0.7-4.9$ & Good \\
\hline $0.2-0.69$ & Moderate \\
\hline $0.1-0.19$ & Weak \\
\hline$<0.1$ & Poor \\
\hline
\end{tabular}

Zones where the conductance is greater than 0.7 mhos are considered as zones of good protective capacity. The portions having conductance values ranging from 0.2 to 0.69 mhos are classified as zones of moderate protective capacity, areas with values ranging from 0.1 to 0.19 mhos are classified as areas of weak protective capacity and the zones where the 


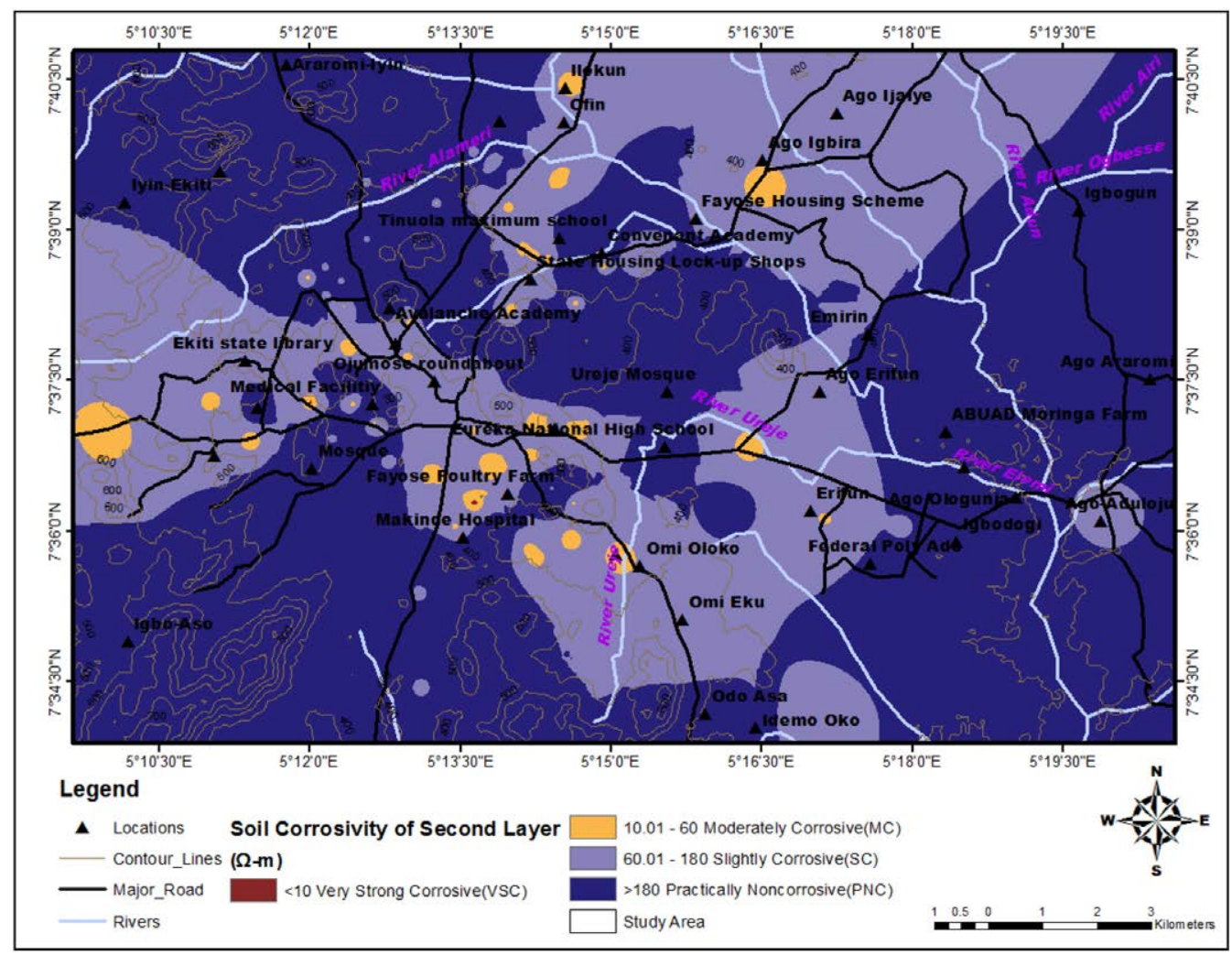

Figure 9: Soil corrosivity map of the second layer.

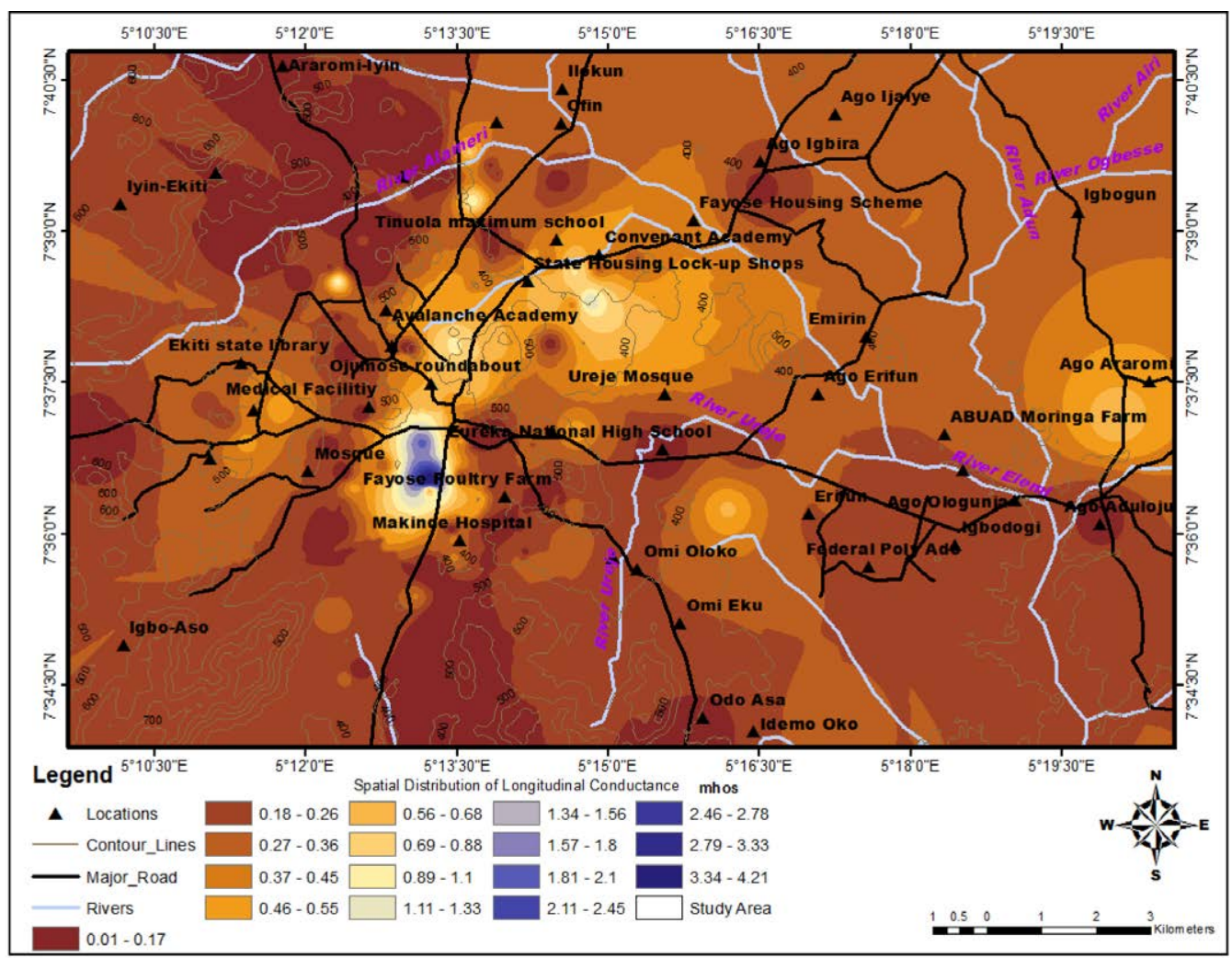

Figure 10: Conductance map of the longitudinal unit. 


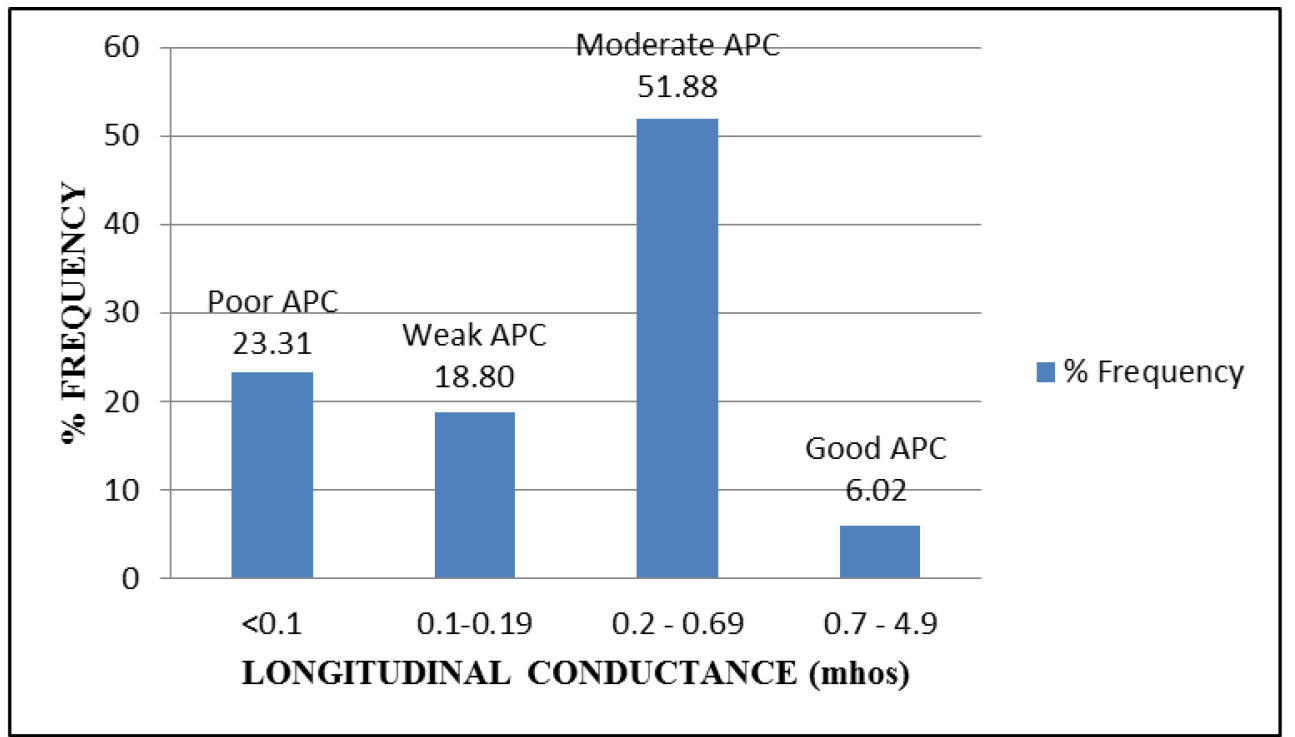

Figure 11: Frequency distribution of aquifer protective capacity.

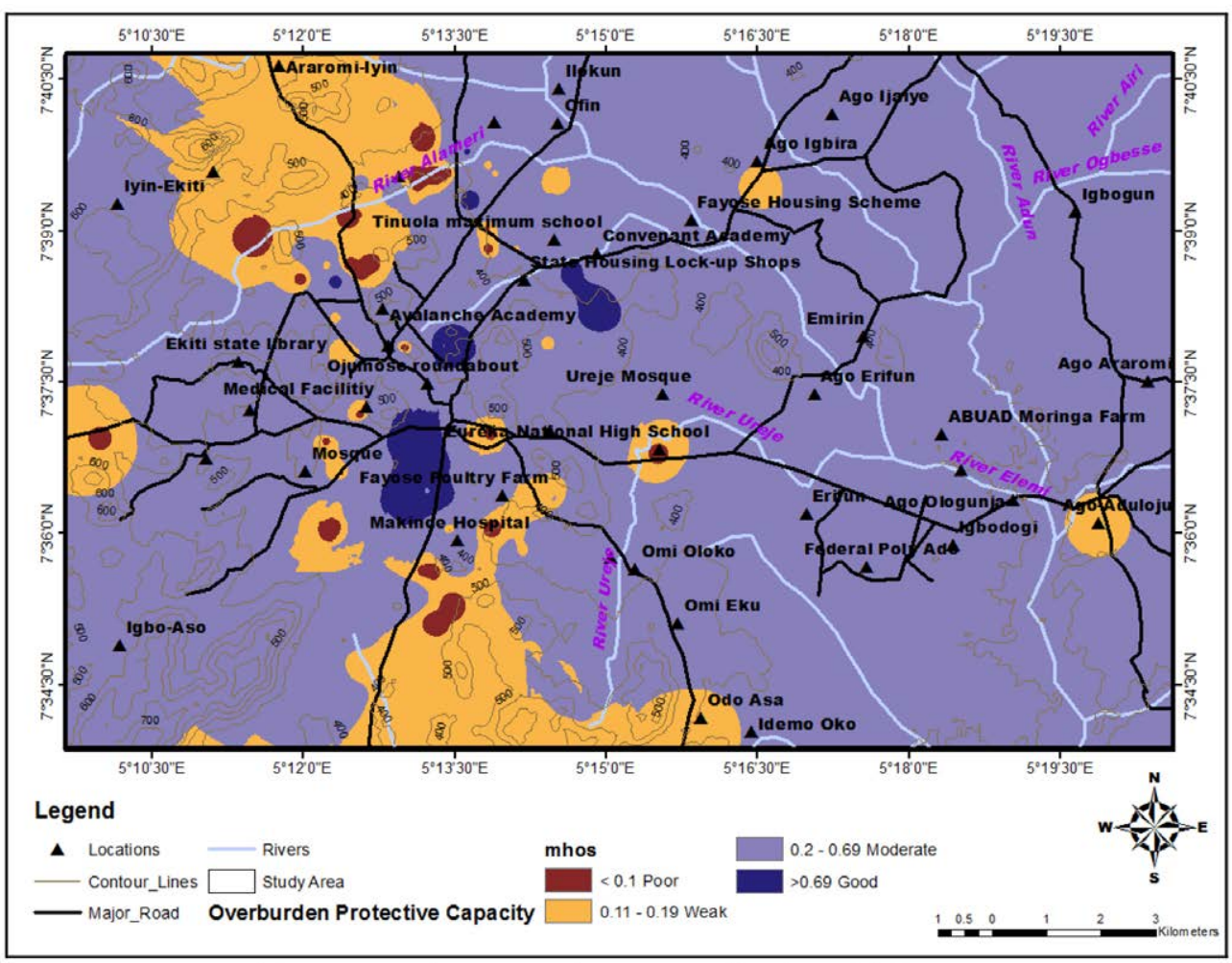

Figure 12: Aquifer protective capacity map of Ado-Ekiti.

conductance values are less than 0.1 mhos are demarcated as regions of poor overburden protective capacity. Poor/weak aquifer protective capacity of the overburden units are observed around the northwestern and southern axes (Figure 12).
On a regional consideration, $23.31 \%, 18.80 \%$ and $57.9 \%$ of the study area is characterised by overburden materials of poor, weak and moderate protective capacity, respectively. Only $6.02 \%$ of the area indicates good overburden protective capacity. This scenario suggests ap- 
preciable caution in safety practices in well completions and general quest for groundwater protection in the metropolis.

\section{Conclusions}

Evaluation of the soil corrosivity and aquifer protective capacity of overburden units in Ado-Ekiti, southwestern Nigeria, had been conducted. Corrosion of cast iron, ductile iron and steel in soils can lead to a range of failures especially in pipelines and buried storage tanks. Integrity assessment of subsurface infrastructure, such as buried steel components, pipelines and steel sheet piles, requires an understanding of the local conditions. Assessment of soil corrosivity is thus germane to design of pipe networks as it provides a useful guide in the selection and prescription of the subsurface steel pipes for a given project and perhaps any required treatment to forestall economic waste and varied hazards associated with the rupture of corroded pipes. Poor, weak, moderate and good aquifer protective capacity zones were delineated in the study area. Areas characterised by poor and weak/moderate aquifer protective capacity should be void of potential contaminant load to ensure overall protection of the groundwater resource. Use of corrosion-resistant pipes is recommended according to the corrosivity level and the design specifications.

\section{Acknowledgement}

We acknowledge with thanks all sources of ancillary data for this work. We appreciate the constructive criticisms and useful suggestions of the Editor-in-Chief and the anonymous reviewers.

\section{References}

[1] Akintorinwa, O.J, Abiola, O. (2011): Sub-soil evaluation for pre-foundation study using geophysical and geotechnical approach. Journal of Emerging Trends in Engineering and Applied Sciences, 2(5), pp. 858-863.
[2] Saupi, S.R.A., Sulaiman, M.A, Masri, M.N. (2015): Effects of Soil Properties to Corrosion of Underground Pipelines: A Review. Journal of Tropical Resources and Sustainable Science, 3, pp. 14-18.

[3] Roberge, P.R. (2008): Corrosion Electrochemistry. In Corrosion Engineering: Principles and Practice, Roberge, P.R. (ed.), McGraw-Hill Education, pp. 35-47.

[4] Adesida, A., Faleye, E.T, Fatoba, J. (2002): Electrical Resistivity Survey for Corrosive Soils at WAPCO, Ewekoro Factory, Ogun State, Nigeria. Journal of Science and Technology Research, 1(1), pp. 22-32.

[5] Gopal, M. (2010): Corrosion Potential Assessment, The Geology of part of South-western Nigeria. Geological Survey of Nigeria, pp. 31-87.

[6] Braga, A.C.O., Filhow, W.M, Dourado, J.C. (2006): Resistivity (DC) Method Applied To Aquifer Protection Studies. Brazilian Journal of Geophysics, 24(4), pp. 573-581.

[7] Oladapo, M.I., Mohammed, M.Z., Adeoye, O.O., Adetola, B.A. (2004): Geoelectrical Investigation of the Ondo State Housing Corporation Estate, Ijapo Akure, Southwestern Nigeria. Journal of Mining and Geology, 40(1), pp. 41-48.

[8] Ehirim, C.N., Nwankwo, C.N. (2010): Evaluation of aquifer characteristics and groundwater quality using geoelectric method in Choba, Port Harcourt. Archives of Applied Science Research, 2(2), pp. 396-403.

[9] Tsepav, M.T., Adamu, Y., Umar, M. A. (2015): Evaluation of Aquifer Protective Capacity and Soil Corrosivity Using Geoelectrical Method. International Scholarly and Scientific Research \& Innovation, 9(11), pp. 662-671.

[10] Mallam, A, Emenike, E.A. (2008): Preliminary Findings of Subsurface Characteristics From Direct Current Resistivity Survey of The Federal Capital Territory (FCT), Nigeria. International Journal of Pure and Applied Sciences, 2(2), pp. 68-76.

[11] Ojo, E.O., Adelowo, A., Abdulkarim, H.M and Dauda, A.K. (2015): A Probe into the Corrosivity Level and Aquifer Protective Capacity of the Main Campus of the University of Abuja, Nigeria: Using Resistivity Method, Physics Journal, 1(2), pp. 172-178.

[12] Olajuyigbe, A.E. (2010): Sustainable Water Service Delivery: An Assessment of a Water Agency in a Rapidly Urbanizing City in Nigeria. Journal of Sustainable Development, 3(4), pp. 210-219.

[13] Rahaman, M. A. (1988): Recent advances in the study of the Basement Complex of Nigeria. In Oluyide et.al. (eds.), Precambrian Geology of Nigeria. Geological Survey of Nigeria: Kaduna, pp. 157-163. 
[14] Kleiner, Y., Rajani, B, Krys, D. (2010): Impact of Soil Properties on Pipe Corrosion: Re-examination of Traditional Conventions. Water Distribution System Analysis-WDSA 2010, Tucson, AZ, USA, pp. 12-15.

[15] Elarabi, H, Elkhawad, T. (2014): Evaluation of Subsoil Corrosivity Condition around Baracaia Area using the Electrical Resistivity Method, A Case Study from the Muglad Basin, Southwestern Sudan. Journal of Earth Science and Engineering, 4, pp. 663-667.

[16] Tijani, M.N, Oke, S.A, Olowookere, A.T. (2014): Hydrogeochemical characterization of a shallow groundwater system in the weathered basement aquifer of Ilesha area, southwestern Nigeria. Evolving Water Resources Systems, 364, 475-489.

[17] Vander Velpen, B.P.A. (1988): Resist Version 1.0. M.Sc. Research Project. ITC: Delft, Netherlands.

[18] Jayeoba, A., Oladunjoye, M.A. (2013): Hydro-geophysical evaluation of groundwater potential in hard rock terrain of southwestern Nigeria, RMZ - Materials \& Geoenvironment, 60, pp. 271-285.

[19] Teikeu, W.A., Ndougsa-Mbarga, T., Njandjock, P.N, Tabod, T.C. (2012): Geoelectric Investigation for Groundwater Exploration in Yaoundé Area, Cameroon. International Journal of Geosciences, 3, pp. 640-649.
[20] Adeniji, A.E., Omonona, O.V, Obiora, D.N, Chukudebelu, J.U. (2014): Evaluation of soil corrosivity and aquifer protective capacity using geo-electrical investigation in Bwari basement area; Abuja. Journal of Earth System Science, 123(3), pp. 491-502.

[21] Ojo, J.S., Olorunfemi, M.O, Akinluyi, F.O., Bayode, S, Akintorinwa, O.J, Omosuyi, G.O. (2015): Evaluating Soil Erosion Risk in the Basement Complex Terrain of Akure Metropolis, Southwestern Nigeria. Journal of Geography and Geology, 7(1), pp. 56-64.

[22] Agunloye, O. (1984): Soil aggressivity along steel pipeline route at Ajaokuta, southwestern Nigeria. Journal of Mining and Geology, 21, pp. 97-101.

[23] Oki, O. A., Egai, A.O, Akana, T.S. (2016): Soil Corrosivity Assessment in the Pre-Design of Sub-Surface Water Pipe Distributary Network in Yenagoa, South-South Nigeria Using Electrical Resistivity. Geosciences, 6(1), pp. 13-20.

[24] Obiora, D.N, Ajala, A.E, Ibuot, J.C. (2015): Evaluation of aquifer protective capacity of overburden unit and soil corrosivity in Makurdi, Benue state, Nigeria, using electrical resistivity method. Journal of Earth System Science, 124(1), pp. 125-135. 
